\section{Wright Memorial}

The first meeting off the 1987-88 year began with a presentation by Steve Brown of the Dayton Lighter Than Air Society on ballooning meteorology. Brown showed slides of balloon races he had participated in, talked about the conditions necessary to fly balloons, and described the weather forecasts provided. In October, Patrick Haines, a Ph.D. student at Purdue University, spoke on forecasting icing and evaluating the Smith-Feddes model. In November, we met at the Stillwater Winery. Unfortunately the speaker had to cancel, but we had a good time tasting different types of wine. The December meeting featured Chuck Hurley of the University of Dayton Reseach Institute. Mr. Hurley, who is the head of the Aerospace Vehicle Coatings Group, talked about rain erosion of different types of materials and showed many pictures of raindamaged aircraft.

We started off 1988 by taking a tour of WDTN-Channel 2's weather station. Brian Davis was the tour guide. In February, Donald Holland, a graduate student at the Air Force Institute of Technology, talked about lightning hazards to space operations. March's meeting featured Chris Church of Miami University, who showed a video of the Minneapolis tornado of 1987 and gave us a tour of the Tornado Research Facility. Tom Stoops, the guest speaker at the April meeting, spoke about sail planing and meteorology. Stoops showed two videotapes of sail planing, described the three types of sail planing, and discussed forecasting techniques. Our May meeting closed out the year with the election of new officers and Candis Weatherford recalling her experiences as a hurricane hunter.

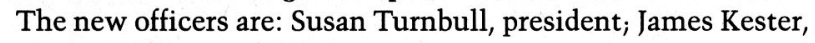
vice-president; and Brian Davis, secretary-treasurer.

As usual, our AMS members judged at several local science fairs. We judged at the Wright State Science Fair in Fairborn, the Otterbein Battelle Science Fair in Westerville, and a science fair in Delaware, Ohio.

Bob Dean did a fine job of running our forecast contest for the past year. The winner was Steve Zahn from Detachment $1,2^{\text {nd }}$ Weather Squadron at Wright-Patterson AFB.

\section{Los Angeles}

At our October meeting, we were pleased to have as our guest speakers Bob Harris, the sailplane altitude record holder, and Doug Armstrong, the meteorologist that helped make his record flight a reality. Harris, who is the president of $\mathrm{K} . \mathrm{H}$. Metal and Supply in Riverside, California, spoke on how he waited five years for the proper conditions for his record 49,000 foot flight. He told us of how he overcame problems with instruments, breathing, and icing during his quest for the record. He then showed many breath taking slides from the flight.

Next, Doug Armstrong, meteorologist at WSFO Reno, Nevada, went over the ideal weather conditions for such an extraordinary flight, and the actual conditions that occurred

\footnotetext{
${ }^{1}$ Meeting reports received at headquarters before 15 July 1988 are included. Copy from chapter representatives should be typed double-spaced and submitted to the news editor in duplicate.-News Ed.
}

that February afternoon. Most of our members left this meeting both impressed and inspired.

\section{Monterey Peninsula}

This chapter held its annual banquet on Friday 3 June, at the Hilton Hotel in Monterey. A total of 33 members and guests attended.

Following a brief introduction by Paul Tag, chapter president, the featured speaker for the banquet, Len Snellman, the chief meteorologist for the Voyager, was introduced. Snellman gave an enthralling account of the Voyager trip, particularly as it was affected by the weather and weather forecasts. Aided by both $35 \mathrm{~mm}$ slides and videotape, he recounted many situations which required critical decisions regarding the aircraft's route, particularly as the result of severe operating restrictions required by the Voyager aircraft.

The chapter's activities this past year have revolved around monthly luncheon meetings that were held at the Naval Postgraduate School in Monterey. Speakers ranged from a local TV meteorologist to a representative from the Sierra Club discussing water alternatives in our area, particularly as they relate to the preceding two drought years in California. The annual banquet culminated the present officer's year of duty; elections for new officers will be held shortly.

\section{Northwest Louisiana}

The second year of this chapter began with a meeting on 2 June 1988 at Abe's Restaurant in Shreveport, Louisiana. President Bob Miller called the meeting to order and presented the current chapter officers who were elected at our May meeting. Miller also stated his pleasure with the growth of the chapter in its charter year, and stressed that the chapter is open to everyone with an interest in meteorology, not just operational meteorologists. Program Committee Chairman Ernie Ethridge presented a list of possible subjects and speakers for upcoming meetings, including a presentation at our next meeting by state climatologist Robert Mueller of Louisianna State University. Ethridge introduced an open discussion of the current extended dry spell in the Arkansas-LouisiannaTexas area, which was moderated by Scott Breit. Local attention had been focused on this topic recently since Shreveport has just experienced the driest May in over 100 years, with only 0.42 inches of rainfall at the Shreveport Regional Airport. Discussion centered on the fact that this dry spell had its beginnings not just in the month of May, but in the previous months of this spring, which were also abnormally dry. This has depleted local water levels and has had damaging effects on the local farm economy. Members then talked about how this situation would be relieved both in the short-term and in the long-term by afternoon thunderstorms, which will be the predominant type of rainfall for the next several months. The central theme of the discussion was that the effects of the dry spell depend upon the perspective of the individual; while this dry period is hurting water supplies and local farmers, it has been beneficial to local construction and to flying operations at Shreveport and Barksdale AFB. The discussion ended with several members making predictions for the coming tropical storm season, and how it could relieve the current situation. 


\section{El Paso-Las Cruces}

The May meeting was called to order at the White Sands Missile Range Officers' Club by the new chapter president, Robert Scheinhartz. Twenty-five members and guests were present. As the first order of business, the president introduced himself and the other new chapter officers, vice-president Steve Kirby and secretary-treasurer Lou Luces.

Under old business, the results of the AMS judging of the El Paso Science Fair were announced. Seventh-grader Amy Shaw won first prize for constructing a working weather station with instrument shelter. She was awarded a NOAA weather radio. Enrique Garcia won second place and an AMS certificate for his project on acid rain.

Scheinhartz announced our participation in "Severe Weather Awareness Week." Over the weekend on 6 and 8 May, members Steve Fortenberry (the El Paso MIC) and Bruce Bradley manned booths at El Paso's Cielo Vista Mall and Las Cruces' Mesilla Valley Mall. They were assisted at the Cielo Vista Mall by member and local TV meteorologist John Fausett. Bruce Miers (chapter past president) and Bob Scheinhartz assisted at the booth in Las Cruces. Information was distributed to several hundred persons through their efforts.

The president then introduced our guest speaker, Henry Rachele of the US Army Atmospheric Sciences Laboratory, who presented his talk entitled "Low-Stratus-Cloud Parcel Dynamics." Rachele explained that this model was intended to aid research into transmission through subcloud and lowstratus cloud regimes. This model would generate vertical profiles of temperature, pressure, specific humidity, potential temperature, etc. All the profiles were thermodynamically inter-consistent.

Rachele concluded by giving credit to Sue Hansen, Arnold Tunick, John Cruncleton, and Neal Kilmer for work on parts of the model and his presentation.

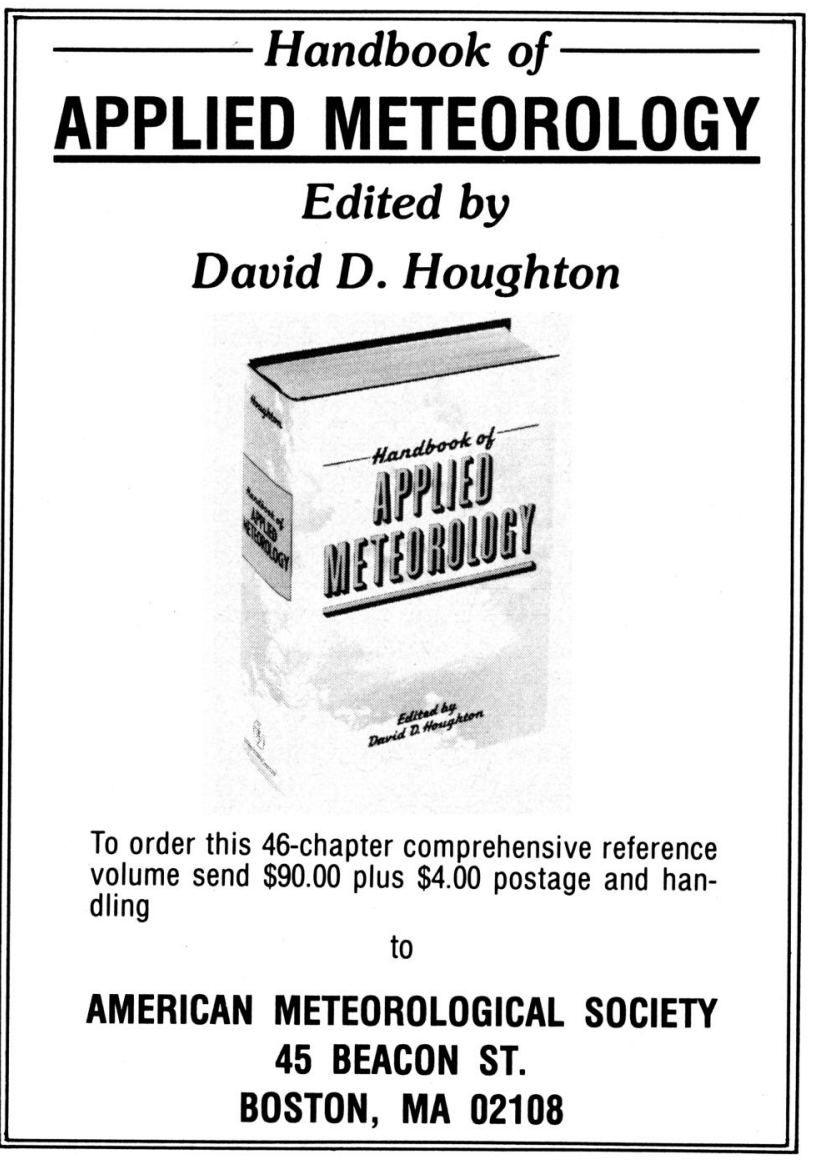

\section{Probing the Atmospheric Boundary Layer}

Published in May 1986

\section{Donald A. Lenschow, Editor}

This volume provides a comprehensive introduction to instruments and techniques for probing the atmospheric boundary layer. The twelve chapters, all by experts in their fields, come from a short course sponsored by the American Meteorological Society. All have been extensively reviewed and modified where necessary for inclusion in this collection. The book covers both direct and remote-sensing technology, including instrumentation for tower measurements, aircraft measuring techniques, fine-scale turbulence measurements, radars, lidars, sodars, particle measurements, visibility measurement techniques, aerosol assessments, and gaseous tracer technology.

Intended for students and practicing atmospheric researchers alike, the book represents the first comprehensive collection of its kind. It includes numerous charts, graphs, and other visual aids. It should prove to be an indispensable tool for all those interested in the field of boundary-layer measurements.

Members $\$ 30.00$

Nonmembers 40.00

please add $\$ 3.00$ postage and handling
Send order and remittance to:

AMERICAN METEOROLOGICAL SOCIETY

45 Beacon St.

Boston, MA 02108 


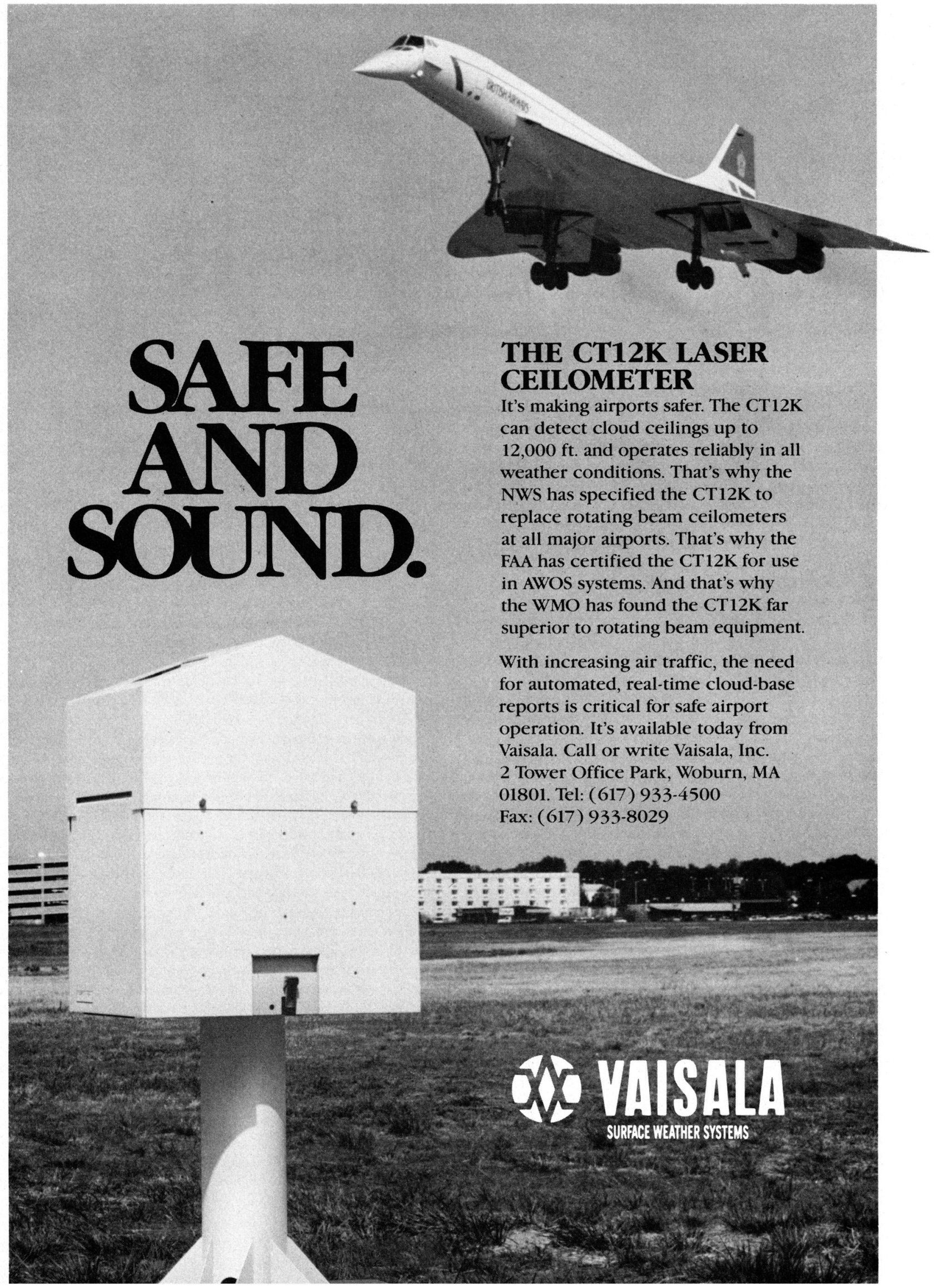

